\title{
Urothelial (Transitional Cell) Carcinoma of the Prostate pT1 TNM Finding v7
}

National Cancer Institute

\section{Source}

National Cancer Institute. Urothelial (Transitional Cell) Carcinoma of the Prostate PT1

TNM Finding v7. NCI Thesaurus. Code C89381.

Urothelial (transitional cell) carcinoma of the prostate with tumor invading urethral subepithelial connective tissue. (from AJCC 7th Ed.) 